\title{
BRPKM
}

Buletin Riset Psikologi dan Kesehatan Mental

http://e-journal.unair.ac.id/index.php/BRPKM

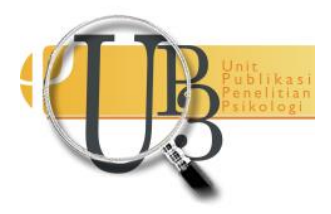

ARTIKEL PENELITIAN

\section{Pengaruh Paparan Media Sosial terhadap Perilaku Self-Harm pada Pengguna Media Sosial Emerging Adulthood}

\author{
RISMA AMELIA WIDYAWATI \& AFIF KURNIAWAN*
}

Departemen Psikologi Klinis dan Kesehatan Mental, Fakultas Psikologi Universitas Airlangga

\begin{abstract}
ABSTRAK
Penelitian ini bertujuan untuk menguji pengaruh paparan media sosial terhadap perilaku self-harm pada pengguna media sosial emerging adulthood. Penelitian melibatkan 227 subyek, dengan rentang usia pada masa emerging adulthood yaitu 18-25 tahun dengan menggunakan metode survei online. Alat ukur paparan media sosial dan alat ukur self-harm disusun peneliti sendiri, memiliki koefisien reliabilitas cronbach alpha $(\alpha=0.922)$ sedangkan alat ukur self-harm memiliki koefisien reliabilitas cronbach alpha $(\alpha=0.942)$. Hasil analisis data menunjukkan bahwa paparan media sosial memiliki pengaruh signifikan terhadap perilaku self-harm. Paparan media sosial dapat mempengaruhi perilaku self-harm pada pengguna media sosial emerging adulthood sebesar 45.8\% $(R=0.458, p<0.05$, $F(227)=190.003)$.
\end{abstract}

Kata kunci: emerging adulthood, paparan media sosial, pengguna media sosial, self-harm

\section{ABSTRACT}

This research aims to determine the influence of social media exposure towards self-harm behavior on emerging adulthood social media users. This research uses survey method and involve 227 subjects, with an age range in emerging adulthood period, 18-25 years old. Social media exposure and self-harm measuring instrument arranged by the researcher has a cronbach alpha reliability coefficient $(\alpha=0,922)$ and the reliability of the self-harm scale $(\alpha=0.942)$. The result of the data analysis showed that social media exposure has a significant influence on self-harm behavior Social media exposure can influence self-harm behavior on emerging adulthood social media users by $45.8 \%$ ( $\mathrm{R}=0.458, \mathrm{p}<0.05$, $\mathrm{F}(227)=190,003)$.

Keywords: emerging adulthood, self-harm, social media exposure, social media users

Buletin Penelitian Psikologi dan Kesehatan Mental (BRPKM), 2021, Vol. 1(1), 120-128

*Alamat korespondensi: Fakultas Psikologi Universitas Airlangga, Kampus B Universitas Airlangga Jalan

Airlangga 4-6 Surabaya 60286. Surel: afif.kurniawan@psikologi.unair.ac.id

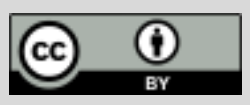

Naskah ini merupakan naskah dengan akses terbuka dibawah ketentuan the Creative Common Attribution License (CC-BY-4.0) (http://creativecommons.org/licenses/by/4.0), sehingga penggunaan, distribusi, reproduksi dalam media apapun atas artikel ini tidak dibatasi, selama sumber aslinya disitir dengan baik. 


\section{PEN D A H U L U A N}

Pesatnya kemajuan teknologi dan informasi dalam beberapa tahun terakhir menjadikan internet sebagai suatu alat yang paling diminati di berbagai belahan dunia. Internet dapat diakses oleh semua kalangan, mulai dari pelajar, mahasiswa, karyawan, dsb. Perkembangan internet bertumbuh dengan pesat menghadirkan fitur yang sangat beragam dan bervariasi salah satunya media sosial, media sosial termasuk dalam golongan media yang populer. Pengertian media sosial sendiri ialah interaksi sosial antara manusia dalam memproduksi, berbagi dan bertukar informasi, mencakup sebuah gagasan ataupun berbagi konten dalam komunitas virtual (Ahlqvist, Toni; Back, A.; Halonen, M.; Heinonen, S, 2008; Sulianta, 2015).

Indonesia merupakan salah satu negara dengan jumlah pengguna media sosial terbanyak di dunia, di lansir dalam Qwords yang menayangkan survei APJII (Asosiasi Penyelenggara Jaringan Internet Indonesia) pengguna internet dan media sosial mencapai 73.7\% dari jumlah total penduduk Indonesia. Menurut Badan Pusat Statistik, jumlah penduduk Indonesia pada tahun 2018 mencapai 264.16 juta dan pada tahun yang sama pengguna internet mencapai $73,7 \%$ seluruh dari masyarakat Indonesia yang berarti mencapai 196.700 juta pengguna (Jatmiko, 2020) sedangkan menurut usia pengguna media sosial di Indonesia paling banyak berada pada rentang usia 18-25 tahun dengan prosentase sebesar $32,3 \%$ (Annur, 2020). Usia 18-25 disebut dengan masa emerging adulthood, mereka banyak menggunakan media sosial, karena pada periode usia ini memiliki fungsi untuk mengembankan otonomi diri, melakukan eksplorasi identitas, dan memulai serta membangun hubungan (Arnett, 2000; Coyne, dkk., 2013) emerging adulthood disebutkan sebagai periode yang sering mengalami ketidakstabilan dan sering memunculkan perilaku maladaptif, media sosial disebutkan memiliki peran yang penting dalam memunculkan perilaku tersebut (Ohannessian, dkk., 2017) pada periode ini juga dikaitkan sebagai periode kritis dalam proses perkembangan (Johnston, O'Malley, Bachman, Schulenberg, \& Miech, 2015; Masten et al., 2008; Ohannessian, dkk., 2017).

Daine, dkk. (2013) menjelaskan bahwa adanya kemudahan akses pada media sosial menghadirkan dampak negatif yaitu menjadikan kemungkinan peniruan perilaku berbahaya dan emerging adulthood memiliki faktor resiko yang lebih tinggi untuk melakukan sebuah peniruan dalam melihat kontankonten yang mereka akses (Phillips \& Sanzone, 1988; Jonas, 1992) meskipun begitu media sosial juga memberikan dampak positif dan efek yang bermanfaat seperti mendapatkan informasi dengan mudah hingga saling memberikan dukungan satu sama lain (Akram \& Kumar, 2017). Hadirnya sisi negatif dan positif dari media sosial menjadikan kita berkewajiban untuk memiliki digital literasi yang baik agar dalam bersosial media dapat menentukan pilihan yang bijak, namun sayangnya di Indonesia yang memiliki prosentase penggunaan media sosial yang tinggi belum dibarengi dengan digital literasi yang mencukupi, Kominfo (2020) menyebutkan bahwa digital literasi yang dimiliki oleh Indonesia masih pada tahap sedikit diatas sedang (Kominfo, 2020), dari 63 negara Indonesia masih berada pada peringkat ke 56 (Kamailah, 2020).

Topik pembahasan dan informasi yang dibahas dalam media sosial di Indonesia juga sangatlah beragam dan menjadikan perlunya pengetahuan lebih terkait digital literasi, salah satu topik yang menjadi pembahasan dalam media sosial yaitu topik mengenai kesehatan mental. Kesehatan mental ialah keadaan kesejahteraan di mana individu menyadari kemampuannya, dapat mengatasi tekanan kehidupan dengan normal, dapat bekerja secara produktif serta mampu memberikan kontribusi kepada lingkungan sekitarnya (World Health Organization, 2020). Munculnya topik kesehatan mental yang dibicarakan pada media sosial juga menghadirkan pengaruh positif maupun negatif, pengaruh positif tentang kesehatan mental menjadikan masyarakat sadar terhadap perilaku, pengurangan isolasi bagi penderita, hingga dorongan pemulihan penderita, sedangkan dampak negatif yang diberikan adalah 
seperti peniruan perilaku dan peningkatan faktor resiko yang tidak dapat dianggap sepele (Brown R, 2018). Topik pembahasan kesehatan mental yang muncul pada media sosial seperti membagikan dan mengunggah perilaku atau perasaan yang ia alami kesedihan, emosi kemarahan hingga perilaku putus asa seperti melakukan tindakan menyakiti diri sendiri atau yang disebut dengan self-harm.

Perilaku self-harm didefinisikan sebagai sebuah perilaku dan niat yang menggambarkan percobaan melukai diri, merusak diri secara impulsif guna mengalihkan emosi atau perasaan yang tak tertahankan (Skegg, 2005). Self-harm dilakukan oleh banyak orang sebagai strategi mengatasi ekspresi tekanan emosional dan proses pengalihan atau melarikan diri dari situasi yang sulit (Hawton \& James, 2005; Paes, 2017). Menurut WHO (2018) perilaku self-harm (melukai diri sendiri) dan bunuh diri adalah penyebab kematian kedua di dunia diantara usia 18 hingga 29 tahun (World Health Organization, 2018). Di Indonesia sendiri, menurut data dari survei YouGov Omnibus pada Juni tahun 2019 menunjukkan lebih sepertiga setara dengan 36,9\% orang Indonesia pernah melukai diri mereka dengan sengaja. Dari persentase tersebut, prevalensi tertinggi ditemukan pada kelompok usia 18-24 tahun dari demografi tersebut sebanyak $45 \%$ responden pernah melakukan self-harm, yang berarti 5 dari anak muda terdapat 2 anak yang pernah melakukan self-harm, sementara 7\% dari responden pernah melakukan self-harm dengan frekuensi rutin (Sasonto, 2020).

Upaya bunuh diri dan cedera diri non-bunuh diri (NSSI) atau disebut dengan self-harm juga menjadi masalah kesehatan yang sering dijumpai di kalangan anak muda (Chan, dkk., 2018). Self-harm disebutkan lebih cenderung dan umum dilakukan oleh wanita daripada pria. Menurut Skegg (2005) selfharm besiko paling besar dilakukan oleh para wanita yang berusia 15-24 tahun dan pria yang berusia 25-34 tahun.Beberapa waktu akhir ini, di lansir dari CNN bahwa terjadi insiden Molly Russell, seorang remaja di Inggris yang melakukan bunuh diri pada 2017. Orang tua Molly menyalahkan sosial media, terutama Instagram ketika mereka menemukan bahwa korban mengikuti akun-akun yang menampilkan konten depresif, bunuh diri, dan self-harming (CNN, 2019). Lalu apakah benar media sosial memiliki peran dalam munculnya perilaku tersebut? Menurut Boyce (2010) dalam Mars, dkk. (2015) terdapat potensi dampak dari media sosial atau internet sebagai sebuah masalah kesehatan yang terjadi di masyarakat yaitu masalah bunuh diri atau perilaku menyakiti diri sendiri namun sayangnya tidak banyak yang menyadari prevalensi tersebut.

Self-harm terjadi dipengaruhi oleh berbagai hal, faktor, dan latar belakang. Media sosial merupakan salah satu faktor situasional yang mampu mempengaruhi kemunculan perilaku self-harm. Peluang pembaca, pemirsa, atau pendengar untuk melihat atau mendengar pesan atau informasi dalam media tertentu di sebut dengan paparan media sosial (Schultz, 1993). Arendt, dkk. (2019) menjelaskan bahwa paparan media sosial yang menayangkan self-harm dapat menyebabkan peniruan perilaku pada pengguna yang rentan, sesuai dengan konsep dasar teori kognitif sosial dimana individu akan cenderung mengikuti perilaku pemodelan atas perilaku yang ia lakukan (Bandura, 2001). Fenomena penularan perilaku juga disebut dengan 'contagion', contagion merujuk pada penularan bunuh diri dan self-harm, penularan terjadi karena efek yang dihasilkan dari media tradisional maupun media internet (Cheng, dkk., 2014) selain itu, adanya efek imitasi ataupun peniruan perilaku yang disebabkan oleh adanya paparan media sosial yang menayangkan berita atau konten tentang bunuh diri dan self-harm di sebut dengan "werther effect".

Dengan adanya fenomena self-harm yang hadir dan dijumpai pada media sosial serta adanya tingkat prevalensi yang tinggi yang muncul pada individu dengan rentang usia 18-25 tahun atau yang disebut dengan masa emerging adulthood serta menurut Zelkowitz, dkk. (2017) perlu adanya penelitian lebih lanjut terkait perilaku self-harm yang terjadi pada emerging adulthood yang akhirnya memunculkan pertanyaan pada penelitian ini yaitu apakah paparan media sosial dapat mempengaruhi kecenderungan 
pengguna media sosial dengan tingkat usia 18 sampai 25 tahun atau yang disebut dengan masa emerging adulthood (Santrock, 2012) untuk ikut serta melakukan self-harm. Maka dari itu, peneliti ingin mencari pengaruh paparan media sosial terhadap perilaku self-harm pada pengguna media sosial emerging adulthood.

\section{E T O D E}

Pada penelitian ini menggunakan penelitian kuantitatif dengan teknik pengambilan data melalui survei online, variabel bebas (X) paparan media sosial dan variabel tergantung (Y) perilaku self-harm. Karena penelitian ini mencari hasil pengaruh antara paparan media sosial dengan perilaku self-harm, maka dari itu peneliti menggunakan teknik analisis uji regresi sederhana dalam mencari hasil pengaruh antara paparan media sosial dengan perilaku self-harm. Belum terdapat data yang pasti terkait jumlah populasi pengguna media sosial yang melakukan perilaku self-harm, sehingga peneliti menggunakan teknik sampling non-probability sampling yaitu purposive sampling non-probability sampling sehingga memunculkan karakteristik partisipan dalam penelitian ini adalah pengguna aktif media sosial, pernah melakukan self-harm, dan berusia 18-25 tahun.

Peneliti juga melakukan uji G*Powers 3.1.9.2. dengan teknik statistical test linier multiple regression: Fixed model, $R^{2}$ deviation from zero menggunakan tipe a priori power analysis menggunakan effect size sebesar 0,15 yang terhitung medium dengan statistical power sebesar 95\% dan alpha sebesar 5\% yang menghasilkan sampel sebesar 89 partisipan. Sebelum partisipan mengisi dua instrumen yang disediakan oleh peneliti, partisipan harus mengisi informed consent pada bagian pertama dan kemudian mengisi dua instrumen alat ukur pada bagian selanjutnya.

Instrumen alat ukur pada penelitian ini dibuat oleh peneliti sendiri, instrumen variabel paparan media sosial berdasarkan dimensi milik Rosengren (1974) yaitu, frekuensi, atensi, durasi dan milik Arendt (2017) yaitu, intentional exposure, emotional disturbance, emotional perspective-taking, presumed copycat influence sedangkan instrumen variabel self-harm berdasarkan dimensi oleh Klonsky \& Gleen (2009) yaitu, frekuensi perilaku self-harm dan alasan melakukan self-harm. Teknik validitas yang peneliti gunakan dalam penelitian ini adalah content validity dengan teknik expert judgement. Reabilitas dari kedua instrumen menggunakan teknik Cronbach's alpha, instrumen variabel paparan media sosial sebesar menghasilkan reliabel sebesar 0,922 dan instrumen variabel self-harm sebesar 0,942. Pada penelitian ini menghasilkan jumlah partisipan sebanyak 227 yang merupakan pengguna aktif media sosial yang pernah melakukan self-harm pada rentang usia 18-25 tahun.

\section{HAS IL P EN ELIT IAN}

\section{Uji Deskriptif}

Uji desktriptif dari penelitian ini menggunakan partisipan sebanyak $\mathrm{N}=227$ dengan nilai terendah variabel paparan media sosial sebesar 61 dan variabel self-harm sebesar 28 sedangkan nilai tertinggi pada variabel paparan media sosial sebesar 163 dan variabel self-harm sebesar 105 . Nilai mean variabel paparan media sosial 98,76 sedangkan variabel self-harm 64,85. 


\section{Uji Korelasi}

Setelah semua uji asumsi terpenuhi, peneliti melakukan uji korelasi untuk mengetahui kekuatan dan arah dari hubungan linear antar dua variabel. Uji korelasi yang dilakukan menggunakan Korelasi Pearson berdasarkan hasil uji korelasi diketahui bahwa terdapat hubungan yang kuat antara dua variabel yang diteliti. Pada kedua variabel dalam penelitian ini menunjukkan nilai korelasi positif yang berarti korelasi antar kedua variabel berbanding lurus, yaitu semakin individu terkena paparan media sosial terkait perilaku self-harm, maka semakin tinggi pula keinginan individu untuk melakukan selfharm (r(227)=-0,677; 95\%; $\mathrm{p}<0.000)$.

\section{Uji Analisis Regresi Sederhana}

Uji asumsi dan uji korelasi telah terpenuhi dan yang terakhir melakukan uji analisis regresi sederhana. Data yang diperoleh dalam penelitian ini menunjukkan $\left(F(1,225)=190,003 ; p<0,000 ; R^{2}=0.458\right)$ dimana variabel independen paparan media sosial dapat mempengaruhi variabel dependen self-harm sebesar $45,8 \%$ persen. Paparan media sosial menghasilkan $(B=0,559 ; 95 \% ; S E=0,041 ; t=13,784 ; p<0,000)$ yang berarti menunjukkan nilai yang positif, sehingga ketika paparan media sosial meningkat, maka perilaku self-harm juga akan meningkat.

\section{I S K U S I}

Perilaku dengan niat yang menggambarkan percobaan melukai diri, merusak diri secara impulsif guna mengalihkan emosi atau perasaan yang tak tertahankan disebut dengan self-harm (Skegg, 2005). Selfharm dapat muncul dipengaruhi oleh beberapa faktor pendukung seperti demographic profil (usia, gender, orientasi seksual, sosial ekonomi), sosial dan family factor (karakteristik keluarga, pengalaman pada masa lampau, agama dsb) hingga faktor situasional meliputi paparan media sosial (Skegg, 2005). Paparan media sosial disebutkan menjadi salah satu faktor resiko paling tinggi untuk memicu munculnya self-harm (Brown, dkk., 2018).

Paparan media sosial adalah peluang pembaca, pemirsa, atau pendengar untuk melihat atau mendengar pesan atau informasi dalam media tertentu (Schultz, 1993). Paparan media sosial menghadirkan sisi positif maupun negatif, seperti mendukung untuk mencari informasi dan saran guna meredam perasaan terkait self-harm, mengurangi perasaan kesepian ataupun isolasi, namun juga memunculkan kekhawatiran akan paparan yang dapat meningkatkan perilaku self-harm pada individu yang rentan terhadap self-harm (Mars, dkk., 2015). Hadirnya paparan yang beragam tersebut sangat berdampak dan memberikan efek campuran pada kesejahteraan para penggunanya, anak-anak dan remaja disebutkan memiliki prevalensi tertinggi (Marchant, dkk., 2017).

Emerging adulthood yaitu masa transisi dari remaja ke dewasa yang berkisar pada usia 18-25 tahun (Santrock, 2012). Emerging adulthood adalah salah satu pengakses media sosial terbanyak dan secara tidak langsung mendapatkan paparan yang juga beragam dan memberikan peran dalam pengelolaan pikiran serta perilaku (Dyson, dkk., 2016). Pada masa emerging adulthood juga disebutkan memiliki faktor resiko yang lebih tinggi untuk melakukan sebuah peniruan dalam melihat kontan-konten yang mereka akses (Phillips \& Sanzone, 1988; Jonas, 1992).

Uji regresi mendapatkan hasil bahwa paparan media sosial memiliki pengaruh yang signifikan terhadap perilaku self-harm pada pengguna media sosial emerging adulthood. Serta menunjukkan bahwa Ha pada penelitian dapat diterima. Hasil analisis regresi linear sederhana yang telah dilakukan mendapatkan hasil $\mathrm{R}=0,677 ; \mathrm{R}^{2}=0,458$ dengan signifikansi $0,000(\mathrm{p}<0,05)$. Hal tersebut membuktikkan bahwa 
variabel paparan media sosial berkorelasi positif dengan derajat kuat $(\mathrm{R}=0,677)$ terhadap self-harm, sehingga ketika paparan media sosial terkait perilaku self-harm tinggi maka perilaku self-harm juga akan meningkat. Selanjutnya koefisien signifikansi pada penelitian ini menunjukkan nilai 0,000 sehingga artinya variabel paparan media sosial berpengaruh signifikan terhadap terbentuknya atau meningkatnya perilaku self-harm.

Nilai R2 (R square) menunjukkan prosentase pengaruh dari variabel paparan media sosial terhadap variabel self-harm sebesar 45,8\%. Hasil dalam penelitian yang telah dilakukan oleh penulis didukung oleh beberapa penelitian sebelumnya yang mengatakan bahwa paparan media sosial dapat memunculkan perilaku peniruan dan penularan atas perilaku bunuh diri, self-harm maupun kekerasan (Daine, dkk., 2013) dan juga disebutkan sebagai tempat fasilitas dari penyebaran informasi terkait penambahan cluster bunuh diri dan self-harm (Marchant, dkk., 2017). O'Connor, dkk. (2014) menemukan bukti bahwa 18\% (N=55/300) dari individu yang melakukan self-harm di pengaruhi oleh paparan media sosial situs jejaring sosial (Oconnor, dkk., 2014). Penelitian lainya di lakukan oleh Mars, dkk. (2015) dimana ia juga menemukan bukti tingginya pengaruh paparan media sosial terkait dengan bunuh diri / self-harm di antara usia 20-21 tahun. Hampir seperempat sampel (886/3946) dalam penelitian tersebut menemukan, mencari informasi, mendiskusikan situs yang membahas tindakan menyakiti diri sendiri atau bunuh diri.

Berdasarkan penormaan self-harm pada penelitian ini menghasilkan hasil tertinggi dengan prosantase $31,3 \%(N=71)$ dengan norma tinggi. Arnett (2014) menjelaskan bahwa eksplorasi identitas pada masa emerging adulthood bisa menjadi suatu hal yang mengasyikkan namun sering kali menyebabkan kebingungan, ketakutan dan kesulitan. Hadirnya hal tersebut cenderung menghambat fungsi dari diri mereka dengan baik dan memunculkan gangguan-gangguan seperti gangguan kecemasan atau gangguan mood. Secara umum perasaan cemas dan depresi adalah perasaan yang biasa terjadi pada masa ini. Survei nasional di AS pada masa emerging adulthood, 56\% (N=1029) dari mereka setuju dengan pernyataan "saya sering merasa cemas" dan 32\% (N=1029) mereka setuju dengan pernyataan "saya sering merasa tertekan" (Arnett et al., 2014).

Emerging adulthood juga menghabiskan waktu yang cukup panjang untuk mengakses media sosial, mereka mengakses media sosial 12 jam perhari (Alloy Media \& Marketing, 2009; Coyne, dkk., 2013) sedangkan menurut Mayo Clinic Health System (2019) penggunaan seberapa lama individu mengakses media yang dapat diterima adalah dua jam perhari untuk usia remaja dan dewasa (Bach, 2019) penggunaan media sosial yang tidak terkontrol secara terus-menerus akan memberikan arah negatif pada individu dan kehidupan mereka seperti sekolah atau pekerjaan, dan kesejahteraan psikologis dan/atau fisik (Andreassen, 2015; Andreassen \& Pallesen, 2014; Bjornsen, 2018) penggunaan media sosial yang obsesif secara negatif juga dikaitkan dengan kemampuan individu untuk mengatur diri sendiri secara kognitif, perilaku, dan emosi (Holmgren \& Coyne, 2017; Bjornsen, 2018). Sesuai dengan penjelasan diatas mengenai emerging adulthood dan klasifikasi mengenai self-harm menurut DSM IV dan ICD-10 F bahwa individu yang melakukan self-harm sering dilaporkan mengalami boderline personality disorder, penyalahgunaan alkohol dan zat; eating disorders; disosiatif, somatoform, atau gangguan dysmorphic tubuh; gangguan depresi dan kecemasan; gangguan stres pasca trauma; dan beberapa gangguan kepribadian dan skizofrenia.

Pada penelitian ini juga menghasilkan prosentase sampel berdasarkan jenis kelamin, dengan prosentase perempuan sebesar 77,7\% ( $=199)$ dan laki-laki sebesar $12,3 \%(\mathrm{~N}=28)$ yang berarti dari segi kuantitas dalam penelitian ini perempuan memiliki kecenderungan lebih besar untuk terpengaruh paparan media sosial dan melakukan perilaku self-harm. Adanya temuan pada penelitian ini didukung oleh penelitian yang telah dilakukan oleh (Mars, dkk., 2015) bahwa wanita dilaporkan lebih banyak menggunakan 
media sosial dibanding pria hal tersebut berkaitan dengan proporsi melukai diri sendiri yang tinggi oleh wanita selain itu penggunaan media sosial yang berlebihan juga berpengaruh dalam beberapa munculnya gangguan psikopatologi termasuk pikiran untuk melakukan bunuh diri dan self-harm. O'Connor (2014) juga menyebutkan bahwa satu dari sepuluh remaja melaporkan pernah melukai diri sendiri pada tahap tertentu dalam hidup mereka dan anak perempuan $3 \frac{1}{2}$ kali lebih memiliki prevalensi tinggi daripada remaja laki-laki (Oconnor, dkk., 2014). Laye Gindhu (2005) juga mendukung hasil dari penelitian-penelitian yang telah disebutkan sebelumnya bahwa wanita cenderung lebih banyak melakukan self-harm daripada pria, pada penelitian tersebut sebanyak 42\% $(\mathrm{N}=424)$ remaja dilaporkan melakukan self-harm dan wanita lebih banyak melakukan self-harm sebanyak 53\% sedangkan pria hanya sebesar 28\% (Laye-Gindhu \& Schonert-Reichl, 2005).

\section{S I M P U L A N}

Penelitian ini berfokus pada peran paparan media sosial terhadap perilaku self-harm pada pengguna media sosial emerging adulthood. Berdasarkan analisis hasil penelitian yang sudah didapatkan, bahwa paparan media sosial memiliki pengaruh yang signifikan terhadap perilaku self-harm pada pengguna media sosial emerging adulthood. Dengan hasil kolerasi positif dengan derajat kuat terhadap self-harm, sehingga ketika paparan media sosial terkait perilaku self-harm tinggi maka perilaku self-harm juga akan meningkat.

Dari hasil penelitian ini disarankan untuk penelitian selanjutnya dapat mengambil sampel populasi yang lebih luas tanpa terfokus pada salah satu periode rentang usia, agar lebih mengetahui dinamika yang lebih beragam pada setiap periode rentang usia karena melihat pengguna media sosial yang datang dengan latar belakang usia yang berbeda-beda, dapat memperluas penelitian dengan menggunakan determinan faktor lain yang mendukung adanya kemunculan perilaku self-harm, sehingga informasi dan langkah preventif guna pencegahan self-harm lebih beragam, penelitian selanjutnya juga dapat menjelaskan bentuk self-harm mana yang lebih cenderung dilakukan oleh masing-masing gender dan menjelaskan demografi dari subjek yang mungkin dapat menjadikan pembahasan tambahan mengenai penambahan perilaku self-harm karena pengaruh paparan media sosial. Selanjutnya dapat melakukan penelitian dengan membedakan media sosial mana yang memiliki kecenderung lebih besar untuk memberikan paparan terkait dengan konten self-harm.

Dari hasil penelitian ini juga menghasilkan saran bagi masyarakat untuk memilih konten secara bijak, paparan media sosial memiliki pengaruh yang cukup tinggi untuk mempengaruhi pengguna media sosial melakukan self-harm dan diharapkan menjadi salah satu langkah preventif dalam penanganan perilaku self-harm .Hal ini juga sekaligus menjadi peringatan bagi para orang tua, yang memiliki anak dibawah umur dalam pengaksesan media sosial sehari-hari melihat tingginya paparan media sosial dapat berpengaruh terhadap perilaku tambahan bagi individu, selain itu dapat menjadi peringatan bagi pengguna media sosial khususnya emerging adulthood untuk lebih berhati-hati untuk membagikan konten-konten yang lebih positif dalam media sosialnya.

\section{U C A P A N T E R I MAKASIH}

Dengan hormat, dengan segala rasa kerendahan hati dan ucapan terima kasih kepada, Afif Kurniawan, M.Psi., Psikolog. Selaku dosen pembimbing skripsi, Ulpianus Sudrajat, S.H dan Imroatul Hasanah, S.Pd selaku orang tua peneliti, dan seluruh kerabat terdekat yang tidak bisa diucapkan satu persatu.

Buletin Riset Psikologi dan Kesehatan Mental (BRPKM) 2021, Vol. 1(1), 120-128 


\section{DEKLARASI POTENSI TERJADINYA KONFLIK KEPENTINGAN}

Risma Amelia Widyawati dan Afif Kurniawan tidak bekerja, menjadi konsultan, memiliki saham, atau menerima dana dari perusahaan atau organisasi manapun yang mungkin akan mengambil untung dari diterbitkannya naskah ini.

\section{PUSTAKA ACUAN}

Akram, W., \& Kumar, R. (2017). LIT REVIEW - BUT Good Suggestions - A Study on Positive and Negative Effects of Social Media on Society. International Journal of Computer Sciences and Engineering, 5(10), 351-354.

Annur, C. M. (2020, November 23). Data Books. Retrieved from Berapa Usia Mayoritas Pengguna Media Sosial di Indonesia?: https://databoks.katadata.co.id/datapublish/2020/11/23/berapa-usiamayoritas-pengguna-media-sosial-di-indonesia

Arendt, F., Scherr, S., \& Romer, D. (2019). Effects of exposure to self-harm on social media : Evidence from a two-wave panel study among young adults. https://doi.org/10.1177/1461444819850106

Arnett, J. J., Žukauskiene, R., \& Sugimura, K. (2014). The new life stage of emerging adulthood at ages 1829 years: Implications for mental health. The Lancet Psychiatry, 1(7), 569-576. https://doi.org/10.1016/S2215-0366(14)00080-7

Bach, M. (2019, May 24). 5 tips for reducing screen time. Retrieved from Mayo Clinic Health System: https://www.mayoclinichealthsystem.org/hometown-health/featured-topic/5-tips-forreducing-screen-time

Bandura, A. (2001). Social Cognitive Theory: An Agentic Perspective. Annual Review of Psychology, 52(1), 1-26 doi:10.1146/annurev.psych.52.1.1.

Bjornsen, C. A. (2018). Social Media Use and Emerging Adulthood. Emerging Adulthood: Current Trends and Reserch, April, 223-261.

Brown R, F. T. (2018). \#cutting: non-suicidal self-injury (NSSI) on Instagram. Psychological Medicine, 48: 337-346.

Brown, R. C., Fischer, T., Goldwich, A. D., Keller, F., Young, R., \& Plener, P. L. (2018). \#cutting: Non-suicidal self-injury (NSSI) on Instagram. Psychological Medicine, 48(2), 337-346. https://doi.org/10.1017/S0033291717001751

Chan, S., Denny, S., Fleming, T., Fortune, S., Peiris-john, R., \& Dyson, B. (2018). Exposure to suicide behaviour and individual risk of self-harm : Findings from a nationally representative New Zealand high school survey. 52(4). https://doi.org/10.1177/0004867417710728

Cheng, Q., Li, H., Silenzio, V., \& Caine, E. D. (2014). Suicide Contagion : A Systematic Review of Definitions and Research Utility. 9(9). https://doi.org/10.1371/journal.pone.0108724 
CNN. (2019, Februari 10). Instagram Perketat Aturan Terhadap Konten 'Self-Harming'. Retrieved from CNN Indonesia: https://www.cnnindonesia.com/teknologi/20190208231811-185367647 /instagram-perketat-aturan-terhadap-konten-self-harming

Coyne, S. M., Padilla-Walker, L. M., \& Howard, E. (2013). Emerging in a Digital World: A Decade Review of Media Use, Effects, and Gratifications in Emerging Adulthood. Emerging Adulthood, 1(2), 125137. https://doi.org/10.1177/2167696813479782

Daine, K., Hawton, K., Singaravelu, V., Stewart, A., Simkin, S., \& Montgomery, P. (2013). The Power of the Web: A Systematic Review of Studies of the Influence of the Internet on Self-Harm and Suicide in Young People. 8(10). https://doi.org/10.1371/journal.pone.0077555

Dyson, M. P., Hartling, L., Shulhan, J., Chisholm, A., Milne, A., Sundar, P., Scott, S. D., \& Newton, A. S. (2016). A systematic review of social media use to discuss and view deliberate self-harm acts. PLoS ONE, 11(5), 1-15. https://doi.org/10.1371/journal.pone.0155813

Jatmiko, L. D. (2002, November 10). Teknologi. Retrieved from APJII: 196,7 Juta Warga Indonesia Sudah Melek Internet: https://teknologi.bisnis.com/read/20201110/101/1315765/apjii-1967-jutawarga-indonesia-sudah-melek-internet

Jonas, K. (1992). Modelling and suicide : A test of the Werther effect. 295(1 992), 295-306.

Kamailah, A. (2020, March 11). Detikinet. Retrieved from Literasi Digital Indonesia Ketinggalan Jauh di Dunia: https://inet.detik.com/cyberlife/d-4933782/literasi-digital-indonesia-ketinggalanjauh-di-dunia

Kominfo. (2020, November 20). Kominfo. Retrieved from Hasil Survei Indeks Literasi Digital Nasional 2020, Akses Internet Makin Terjangkau: https://kominfo.go.id/content/detail/30928/siaranpers-no-149hmkominfo112020-tentang-hasil-survei-indeks-literasi-digital-nasional-2020akses-internet-makin-terjangkau/0/siaran_pers

Laye-Gindhu, A., \& Schonert-Reichl, K. A. (2005). Nonsuicidal self-harm among community adolescents: Understanding the "whats" and "whys" of self-harm. Journal of Youth and Adolescence, 34(5), 447457. https://doi.org/10.1007/s10964-005-7262-z

Marchant, A., Hawton, K., Stewart, A., Montgomery, P., Singaravelu, V., Lloyd, K., Purdy, N., Daine, K., \& John, A. (2017). A systematic review of the relationship between internet use, self-harm and suicidal behaviour in young people: The good, the bad and the unknown. PLoS ONE, 12(8), 1-26. https://doi.org/10.1371/journal.pone.0181722

Mars, B., Heron, J., Biddle, L., Donovan, J. L., Holley, R., Piper, M., Potokar, J., Wyllie, C., \& Gunnell, D. (2015). Exposure to , and searching for , information about suicide and self-harm on the Internet: Prevalence and predictors in a population based cohort of young adults. Journal of Affective Disorders, 185, 239-245. https://doi.org/10.1016/j.jad.2015.06.001

Oconnor, R. C., Rasmussen, S., \& Hawton, K. (2014). Adolescent self-harm: A school-based study in Northern Ireland. Journal of Affective Disorders, 159, 46-52. https://doi.org/10.1016/j.jad.2014.02.015 
Ohannessian, C. M. C., Vannucci, A., Flannery, K. M., \& Khan, S. (2017). Social Media Use and Substance Use During Emerging Adulthood. Emerging Adulthood, 5(5), 364-370. https://doi.org/10.1177/2167696816685232

Paes, A. (2017). Self-harm in adolescence. InnovAiT: Education and Inspiration for General Practice, 10(4), 202-208. https://doi.org/10.1177/1755738016673861

Santrock, J. W. (2012). Life Span Development Edisi Ketigabelas Jilid 2. Jakarta : Penerbit Erlangga.

Sarwono, J. (2009). Statistik itu Mudah: Panduan Lengkap untuk Belajar Komputasi Statistik Menggunakan SPSS 16. Yogyakarta: Universitas Atma Jaya Yogyakarta.

Sasonto, A. R. (2020, maret 3). Kita Perlu Lebih Serius Membahas 'SelfHarm'yang Menghantui Anak Muda Indonesia. Retrieved from Vice: https://www.vice.com/id/article/4agbb3/ciri-gejala-selfharm-anak-muda-indonesia-melukai-diri-sendiri-konsultasi-psikologi

Schultz, P. \&. (1993). Values and pro environmental behavior: A five -country survey. Journal of CrossCultural Psychology, 29 (4), 540-558.

Skegg, K. (2005). Seminar Self-harm. 366.

Sulianta, F. (2015). Keajaiban sosial media. In F. Sulianta, Keajaiban sosial media (pp. 5-6). Jakarta: PT Alex Media Komputindo.

Zelkowitz, R. L., Porter, A. C., Heiman, E. R., \& Cole, D. A. (2017). Social exposure and emotion dysregulation: Main effects in relation to nonsuicidal self-injury.Journal of Adolescence, 60, 94-103. https://doi.org/10.1016/j.adolescence.2017.07.015

World Health Organization. (2018). Suicide: Key Facts. Retrieved from World Health Organization (WHO): https://www.who.int/ en/news-room/fact-sheets/detail/suicide

World Health Organization. (2020). Retrieved from https://www.who.int/mental_health/who_urges_investment/en/ 